\title{
THE ITEM RESPONSE THEORY (IRT): ANALYSIS OF ATTITUDE OF UNDERGRADUATE STUDENTS REGARDING THE STATISTICS DISCIPLINES
}

\author{
Etienne Pereira da Silva \\ University of Brasília, Brazil \\ etiennepereira@hotmail.com
}

The poster to be presented proposes to assess the attitude of 210 students from the University of Brasilia (UnB) who answered Attitude Scale regarding Statistics (EAE). Furthermore, this work is the result of the Final Paper of course Bachelor in Statistics at UnB in order to get a better understanding of statistical education and the IRT applicability.

The Item Response Theory (IRT) has considered an alternative to Measure Classical Theory (MCT) in elaboration and analysis of the constructs that are evaluated by the measuring instruments (questionnaires). With wide application in educational assessment, the IRT, whose main feature is the item, proposed probabilistic models for latent variables (variables that are not directly measured).

The researchers have indicated that the students demonstrate low motivation to use statistical instruments and they have some difficulties in learning statistics concepts. Previous studies claim that students with positive attitudes about particular discipline are more likely to succeed in learning of its contents. Thus, the answers were given by students from UnB were analyzed by Item Response Theory.

The parameters of difficulty of the items $\left(b_{i}\right)$ and the discrimination parameter $\left(a_{i}\right)$ showed that the item concerning to definitely has a positive reaction to the service disciplines (Biostatistics, Applied Statistics and Probability and Statistics), appreciate and enjoy this matter was the best informs. The various disciplines (different study areas), perception of performance, attend or not the first discipline shown to influence the attitudes level toward statistics.

These results suggest an enhancement to the statistics is applied in the context of the course each student and what strategies are adopted to develop a teaching-learning environment that encourages students.

\section{REFERENCES}

Andrade, D. \& Tavares, H. \& Valle, R. (2000). Teoria de Resposta ao Item: conceitos, modelos e aplicações. In: SINAPE.

Andrade, D. (2012). Teoria de Resposta ao Item com uso do R. In: SINAPE.

Carzorla, I. (1999). . Adaptação e Validação de uma Escala de Atitudes em Relação à Estatística. In: Conferência Internacional Experiências e Perspectivas do Ensino de Estatística: Desafios para o Século XXI, Florianópolis (p. 45-57).

Gal, I. \& Ginsburg, L. \& Schau, C. (1997) Monitoring attitudes and beliefs in Statistics Education. In: I. Gal \& J. B. Garfield (Org.).Amsterdam: IOS Press (p. 37-51). 